\title{
Civilisations
}

Revue internationale d'anthropologie et de sciences

humaines

$57 \mid 2008$

Tourisme, mobilités et altérités contemporaines

\section{The tourism ordering}

Taking tourism more seriously as a globalising ordering

\section{Adrian Franklin}

\section{(2) OpenEdition}

\section{Journals}

Édition électronique

URL : http://journals.openedition.org/civilisations/1288

DOI : 10.4000/civilisations. 1288

ISSN : 2032-0442

Éditeur

Institut de sociologie de l'Université Libre de Bruxelles

Édition imprimée

Date de publication : 29 décembre 2008

Pagination : 25-39

ISBN : 2-87263-022-8

ISSN : 0009-8140

\section{Référence électronique}

Adrian Franklin, "The tourism ordering », Civilisations [En ligne], 57 | 2008, mis en ligne le 29 décembre 2011, consulté le 05 mai 2019. URL : http://journals.openedition.org/civilisations/1288 ; DOI :

10.4000/civilisations.1288

(c) Tous droits réservés 


\title{
1. Un nouvel ordonnancement?
}

\author{
The tourism ordering \\ Taking tourism more seriously as a globalising ordering
}

\author{
Adrian FRANKLIN
}

Résumé : Cet article commence par clarifier ce que j'entends par "la mise en ordre touristique ». Pendant des années, la théorie du tourisme a été inhibée par une théorisation structuraliste étroite et par la notion de "lieux marginaux ». En conséquence, le tourisme était considéré comme socialement et spatialement marginal par rapport aux activités principales du monde contemporain, et comme un problème. Ses effets plus larges ne furent donc jamais théorisés de façon adéquate. En recourant à un mélange d'idées de Foucault, Latour, Law, Deleuze et Guattari, ainsi qu'à ceux qui plaident pour une sociologie des mises en ordre, la " mise en ordre touristique » cherche non seulement à théoriser la place du tourisme dans les sociétés contemporaines, mais aussi à démontrer l'impact puissant de celui-ci en tant que principe de mise en ordre de la modernité. Sans chercher une rédemption absolue pour le tourisme, cet article cherchera finalement à identifier quelques-uns des effets de mise en ordre les plus positifs et intéressants qu'a eus ce dernier.

Mots-clés : tourisme, ordonnancement, globalisation, modernité.

\begin{abstract}
This paper will start by clarifying what I mean by the tourism ordering. For many years tourism theory was inhibited by narrow structuralist theorising and the notion of 'places on the margin'. Consequently tourism was considered both socially and spatially marginal to the main business of contemporary life and most often a problem in both senses. As a result, its wider effects were never adequately theorised. Using a mix of ideas from Foucault, Latour, Law, Deleuze and Guattari as well as those who advocate a sociology of orderings, the tourism ordering seeks not only to theorise the place of tourism in contemporary societies but to demonstrate its rather potent impact as an ordering of modernity. While not seeking absolute redemption for tourism this paper will seek to identify some of the more positive and interesting 'ordering effects' this ordering has had.
\end{abstract}

Key words: tourism, ordering, globalization, modernity. 


\section{Introduction}

$\mathrm{T}$

his paper will start by clarifying what I mean by the tourism ordering. For many years tourism theory was inhibited by narrow structuralist theorising and the notion of 'places on the margin'. Consequently tourism was considered both socially and spatially marginal to the main business of contemporary life and most often a problem in both senses. As a result, its wider effects were never adequately theorised. This paper begins by setting out the key elements of tourism seen as an ordering. It borrows ideas from a range of scholars including Foucault, Latour and Deleuze and Guatarri and is indebted to those sociologists (Crook 1999; Kendall and Wickham 2001; Hunt and Wickham 1994) who have identified a sociology of orderings as a means of avoiding the problem of 'social order'. Through the notion of orderings these authors retain the possibility of large scale ordering attempts and orderings that, once unleashed on the world, enact repetitions of themselves and spatial extension while at the same time converging and clashing with other orderings. The sociology of orderings recognises the performance of innovation and management and also the scale and heterogeneous nature of agency in orderings. In this paper the work of two men, John Byng and Thomas Cook, illustrate how their interventions in the reordering of travel and tourism had enormous ramifications. However, the sociology of orderings also permits us to see tourism as a network of performance and relational materialism and to lift our eyes from the tourist location, where the bulk of tourism research takes place. This wider view enables us to see a range of ordering effects that are often obscured by micro studies of the sociology of hosts and guests. The paper suggests that we take seriously at least six ordering effects in future research. These are aestheticisation, consumerism, translation, place-making, touristification, and cosmopolitanism. The scope and promise of each of these are outlined in the final section of the paper.

\section{Global tourism as an ordering}

In a previous paper (Franklin 2004) the sociology of ordering was identified as being of potential great interest to theorists of tourism, many of whom have noted its characteristically heterogeneous mix of objects, agency(ies), social networks, non-linear histories, together with its spatially distributed nature and its filamentous, prehensile extension across time and space (Franklin 2003; Franklin and Crang 2001; Johannesson 2005b; Law and Hetherington 1996) ${ }^{1}$. While tourism is seen by many anthropologists as a major reorganizing power in the world, hugely disruptive and destructive of places and cultures (it has been likened to a blight, see for example Young 1973; Wenkam 1975; Pi-Sunyer 1982), it is at the same time regarded by many other anthropologists as a phenomenon scarcely significant enough to merit serious academic attention (see Doquet and Evrard's 2008 interview with Urbain for a fascinating exposition of this in France). In the sociology of tourism there is an equally paradoxical and contrary history of thought. On the one hand tourism was regarded by many as a shallow, vacuous and insignificant activity, on the margins of the more interesting and important dimensions of social life which focused on work rather than leisure (see Franklin 2008 for a summary

1. Some paragraphs of the next sections are borrowed from already published texts (see Franklin 2004, 2007). 
of this literature) while others, including Scott Lash and John Urry (1994) and Zygmunt Bauman (1998, 2000; Franklin 2003b) see it as both structurally and symbolically central. For example, Lash and Urry (1994: 261-4) identified Thomas Cook, an early innovator of modern tourism, as an unrecognized founder of modern life itself: "there is some justification for suggesting that twentieth-century organized capitalism might be better described as 'Cookism' rather than 'Fordism"'. Not only did he create connectivity across the world that others had never imagined, let alone solved technically, but he had also in passing, created such things as credit cards, advanced ticketing; an international travel system, and the first around-the-world ticket. As Brendan (1991: 3) argues, his achievement of mass movement "dwarfs the great migrations of the past and sustains the largest industry in the world". For contemporary sociology so interested in globalization, a man who had so single-handedly done much to shrink the world, as well as produce the relentlessly expanding socio-technical network, has at least to be taken seriously. However, we often miss the distributed nature of this contribution (which I am going to call an 'ordering') and particularly its in-built propensity to enroll more people, places and organizations into its network. Instead, as Franklin and Crang (2001) argued, tourist studies have produced a proliferation of research on tourist sites and destinations, leading to the widely held view that tourism is associated with the social margins (Shields 1991).

Bauman on the other hand has recently noted on several occasions (Bauman 1998; Franklin 2003b) the way in which tourism has become an important metaphor for contemporary social life itself since to be a tourist (to be mobile, travelled, connected and without overriding ties and commitments to a locale) is how a successful life is now measured. Conversely of course to be mired in place, to be tied or fixed to place is often how poverty or failure is frequently expressed. But for Bauman it is even more than this since tourism spawned what he calls the 'tourism syndrome' (see Franklin 2003a) in which the lack of connection and commitment that tourists have to the places they visit is extended into the places they live at other times. In other words, tourism for Bauman perfectly captures the nature of contemporary social bonds which, like the tourist's itinerary and visit, should be fleeting, light and easy, until further notice; an arrangement easily made and easily broken.

In a previous book (Franklin 2003) and paper (Franklin 2004), I have also made the case against seeing modern tourism as merely a new manifestation of an essentially universal form of behaviour, as so many structuralist thinkers tended to do (see for example, MacCannel 1976; Urry 1991), which included an assumption that modern travel and tourism and its antecedents were widely regarded as desirable. However it was very clearly not the mass extension of 'The Grand Tour' or 'the spa' since these were very specifically associated with a social elite whose distinctively mobile culture set them apart from a largely sedentary popular culture, particularly in the United Kingdom. The tradition of Anglo-American tourism theory has always assumed the pleasurability and popularity of tourism through its association with holidays, which had a long antecedence in Christian Europe and before. However, as I have previously shown, one of the most important characteristics of these holy days (revels, festivals, carnivals and so on), and the carnivalesque form they took, was their focus on a local community, village, district, valley or region. They were not based on travel to new places beyond the everyday, but rather the opposite, a convergence on the ritual centre of a locale. Equally, in the British 
and American case, the tradition of pilgrimage was largely terminated with the decline of Catholicism in the $16^{\text {th }}$ century and the arrival of Protestantism.

When Thomas Cook had the radically new idea to extend affordable tourism to most people (in 1841), there was very little traveling culture to build on, much less 'traditions of tourism'. While there were indeed many itinerant and migratory workers and travelling occupations, the idea of travel itself as a form of pleasure barely existed (see also Clifford 1992 for a discussion of travel among non-industrial cultures). Here the structuralist masking of history obscured the fact that the desire for travel had to be created, that in fact even when affordable rail transport was in the grasp of most people, they had to be persuaded, often using novel forms of marketing and inducement, just in order to make them to see the point of it. While Thomas Cook's travel empire became global in scope during his lifetime, he viewed his main task, particularly in the early days as predominantly one of persuasion (Withey 1997). To a largely non-travelling public not used to the idea of tourism or even of the aesthetics of tourist objects, the idea seemed to be patently absurd.

Cook's experience was mirrored by John Byng, another eccentric who had the strange idea that it might be possible to be a tourist in Britain. During the late eighteenth century when tourism was universally associated with the Grand Tour on continental Europe, Byng began a series of 'rides' around Britain during periods of annual leave from his government post in London (Adamson 1996).

He found it almost impossible to obtain information about most regions and districts in advance of travel and often had to study works of art in London galleries to discover landmarks and buildings worthy of visiting. He also found a profound lack of information and interest in the idea of tourism among local people. Typically, local people would be unable to suggest anything in their locality that was worth seeing or travelling to see and even those who were most associated with travel (inn keepers, hostlers etc) were baffled by his requests for information.

When Byng published the accounts of his rides, he made much of the contrast between the presence of so much to interest a tourist in most localities and local indifference to it, but he also noted that few people seemed to know what lay 25 miles beyond their home.

Whereas the absence of a touristic culture in the United Kingdom is surprising, its absence in France, through which the Grand Tour transited, would be remarkable. According to the French tourism sociologist Jean-Didier Urbain, however, in France tourism was for a very long time widely considered to be an English cultural phenomenon (Doquet and Evrard, forthcoming 2008). According to the Larousse, the French Dictionary, 'touriste' was an acceptable synonym for 'English' until around 1890. In nineteenth century France, a travelling and touristic mentality simply did not exist:

In Europe, the specificity of the tourist was not recognised until the end of the eighteenth century. No earlier trace can be found anywhere. It is worth recalling Gustave Flaubert's anecdote about the tourist trip he took to Brittany with his friend Maxime Ducamp in 1847 [...]. On arriving in one village, they found it impossible to convince the inhabitants that they were travelling simply for pleasure. They were taken for spies, surveyors, cartographers, government road inspectors or controllers checking on the work of lighthouse-keepers. In the end, they had to invent an official purpose for their visit, a function, a utility, to cease being incomprehensible, and therefore suspicious, in the eyes of the villagers (Doquet and Evrard 2008: 37). 
The work of people such as Thomas Cook and John Byng together with the texts, organisations and technologies they assembled to make tourism possible, pleasurable and desirable have therefore to be seen as major cultural interventions rather than simply extending, democratizing or adding to something that was already there, but the work they did is very revealing since it was very world changing.

While they themselves were formed by the conditions of their lives, it seems that the nature of their dream and imagination and particularly the way they pursued them in writing/publishing and establishing a new form of travel business were important to try to understand. For what they both did was create the idea of tourism where none had existed before; the objects of tourism, which did not have this quality as things to be visited before, and the means of visitation which had not been widely considered before (British tourism on horseback and tourism by train, tourist maps, guides etc). How important were these dreams, theoretically? How do we theorise the role played by technologies (texts, horse riding, trains, maps and guides)? And what is the ontological nature of the interlinked 'thing' they unleashed on the world that became tourism? One of the problems of tourism theory is that we do not have ready answers to these questions although they are being thought about.

Of course, tourism, as the industry defines it, includes a lot of activities that Thomas Cook would not approve of or even recognize as tourism and there needs to be more clarification of this generally in the literature. How can we reconcile a beach holiday with a literary tour of Shakespeare country with an adrenalin tour of Norwegian fjords? Even though these seem radically different activities Morrell's (1998) diary of an early Cook's tours demonstrates that muscular, intellectual, ludic and aesthetic sensibilities were included on a typical guided tour to Switzerland. It also illustrates Cook's (and later tourism developments into the twentieth and twenty-first centuries) view that while nature, exercise, history, art and culture were always likely to be staples, the point about tourism was to experience other worlds and places which meant that from its earliest days, new and site specific activities were added to itineraries. It was also very clearly the case that tourist companies recognized a diversity of consumer interests and from the very earliest days a choice of side-trips were offered from the main destination hubs. In this way, tourism is inevitably very diverse and tourism seen from the perspective of it historic developments of networks, connections, choices and destinations embodies this diversity.

They also created a touristic stance to the world, a new way of looking at the world and at each other that had not existed beyond a small social elite, largely from one country. This tourist stance and its repertoires of performance have been increasingly imported from the resort, the pleasure beach and National museum into the everyday, and have equipped us to make sense of a globalizing world around us.

We can therefore conjecture that tourism cannot be merely located/associated with the tourism resort or destination because its wider impact is far more significant than its manifestation and effect in any one place. We can say that its implications for connecting the world, extending technologies and desires and inculcating new habits, cultural repertoires, fragmenting local social bonds (strong ties) while at the same time widening our network of global (weak) ties (see Granovetter 1973) and shifting our (most Western people's) stance to the world from 'local' to 'tourist'. While these effects are profound it is not at all easy to conceptualize tourism. 
Far from being conceivable as a form of ludic or ritualistic behaviour reducible to one feature of modernity or another, as it has been the case since tourism was first analysed in the 1960s (see Franklin 2008), we should perhaps see it as a more active social force, alongside other socio-technical structuring processes, such as nationalism, consumerism or even capitalism. To do so requires a very different approach that is capable of handling its simultaneous activities at a number of scales as well as its great diversity of agency, both human and non-human; an approach that is capable of handling what Law has called a 'relational materialism'. The emergent sociology of ordering offers an interesting means of understanding tourism as a form of relational materialism

\section{The sociology of ordering}

The sociology of ordering places much emphasis on both organization and management (Law 1994; Crook 1999; Kendall and Wickham 2001). Orderings are, very loosely speaking, attempts to manage or control. These authors suggest we take more seriously attempts to order (both those that succeed as well as those that fail) as a way of comprehending the presence and persistence (and failure) of orderings as opposed to order itself; order seen as a self standing presence emanating from often hidden structural sources.

To the Latourian and Deleuzian emphasis on network or rhizome, or at least its posthumanist insistence on material heterogeneity, relationality, and the agency of nonhumans, the Foucauldian element of governance is grafted. Ordering is like governance: 'ordering is to governance as government is to order' (Crook 1999) and while order is an impossibility, a never-to-be-attained state in the same way that government always fails, attempts at governance, and ordering attempts, are the very stuff of the world, the way the world operates as a process of becoming. Freed from the need to operate inside the restraints of abstractions such as society, social order, social structure etc, this approach suggests we concentrate on what people and things, people and things together, actually $d o$.

However, the sociology of orderings does not privilege attention only to human interventions in the world and incorporates the radical decentredness of Latour's (1993) insistence on a symmetry of attention to both human and non-human forms of agency. It is interested in other words in a posthumanist ontology, one that does not posit a world of "humans among themselves" (Pickering 1995).

Although humans makes interventions in the world, and make ordering attempts, they always do so in a world in which other orderings are already circulating. While many of these will have been initiated by human agency, all such attempts do so must be in association with already-active constellations of technologies, texts, techniques and other forms of non-human agency. Orderings "are never simply a social matter...but rather a materially heterogenous set of arrangements and processes implicated in and including people to be sure, but also including and producing documents, codes, texts, architectures and physical devices" (Law 2003: 1).

The spatial scales of orderings are often identifiable and limited, ranging from the domestic and personal to global in scope, however their spatial frame is never given in their conception since ordering attempts have a life or biography of their own that cannot be known in advance of their original intention. They enter into a world where they 'meet' and engage with other orderings in unintended circumstances, and in manners of interaction that are hard to predict let along anticipate. Orderings are thus capable of 
mutation and multiplication, rather like viruses, but they are also capable of becoming something very different because they can add to other orderings as others can be folded into them creating very different scales, affectivity and impact.

Ordering then can be of any magnitude and certainly every individual is engaged in ordering activities, from simple ordering of the domestic material objects around them to ordering their movement through space. All organizations, by definition make attempts to order, some larger than others. As Kendall and Wickham (2001) say, ordering is everywhere. And these various ordering attempts or programs once released into the world have a history of their own as they interact with other orderings, especially antiprograms. Some might enable them to change, maybe to expand their power, range or effects; others might set limitations or eliminate them altogether. And of course, since orderings are themselves objects they can be constituted themselves 'by being addressed by an ordering practice' (Kendall and Wickham 2001).

Some ordering attempts have deliberately sought to bring the idea of an exclusive social order. Most of these fail early in their biography and only very rarely do they realize any temporal continuity and even then, rarely in the manner originally conceived. A variety of modern blue prints take this form, those of Garibaldi and Bismarck as nation builders, that of Hitler as builder of national-socialism and that of Lenin and Stalin as builders of communism; those of Hausmann, Howard and Le Corbusier in forms of architecture and city, and so on. However, although most ordering attempts are of a much lower order and magnitude they may, in modified forms have much longer and more profound impacts (e.g. the romantic landscape painting, radio, the internet).

At one level all human projects attempt to manage and control people and things such as hydroelectric systems, banking systems, management systems, the Internet, textual technologies. Law's paper on the machinic pleasures of aircraft travel and Bennett's work on the centrality of technology for the 'Blackpool experience' (Bennett 1983), demonstrates that tourism cannot be a purely social or business activity, or at least its social nature also articulates necessarily and in complex ways with non-human objects, systems, machines, bureaucratic processes, times, timetables, sites, photographs, tents, flows, desires, visitors, businesses, locals, etc. in a complex materially heterogeneous assemblage (Haldrup et al 2006, have recently underlined the materiality of tourism).

Critically, many ordering attempts have blueprint-like beginnings, but as orderings unleashed on the world they persist in time and space and they have a more unbounded and open-ended nature: they may not be confined to their intended object and they may not continue in the form initially conceived having a range of effects intended and otherwise. It is an ontology of unintended consequences, failure, unforeseen agency and promiscuous enrolment. Orderings are pure process. Law and Hetherington argue that "global space" for example "is a material semiotic effect. It has to be made" (Law and Hetherington 1999). I would argue that tourism was an important ordering of global space.

The sociology of ordering was first identified in John Law's Organizing Modernity (1994), which identified narratives of the world at their heart: 'they tell us what used to be or what ought to happen. Here there are ordering concerns, procedures, methods or logics, dreams of ordering perhaps, nothing more. Certainly they are not 'pools of total order' (Law 1994: 9).

While important, these narratives can only find expression through performance, "embodied in a concrete, non-verbal manner in the network of relations...I'm saying, then, that they are imputable ordering arrangements, expressions, suggestions, possibilities 
or resources... [O]rdering involves strategies that are not always explicitly framed or worked strategies, but, like Foucault's discourses are 'forms of strategic arranging that are intentional but do not necessarily have a subject" (Law 1994: 21).

The application of this approach to tourism studies can be readily appreciated, and this framework offers a very useful way of reinterpreting modern tourism as a process of 'becoming connected' but also a way of being in and of the world. It allows us to theorise the role of early innovators, such as John Byng and Thomas Cook, as well as the dreams they realized. Tourism begins to seem less like 'behaviour' confined to distinctive 'tourist sites' and more like a network that enrolls people, objects and places into its extending lineages (heritages, resorts, ethnicities, natures, cityscapes, battlefields, landscapes, adrenaline thrills and so on). It seems less like an industry and more like a rhyzomic assemblage of technologies, governmentalities, texts and 'travel objects' on multiple lines of flight. Seen as an ordering, tourism creates interlocking and prehensile technologies (which reached out to others and explore other possible configurations of technology and culture). It creates touristic predispositions to travel and experience a world wider than the locale and has a built-in tendency to add more experiences, destinations, routes since tourism is based more on desire and curiosity than the search for answers and satisfaction. As more and more places become translated into tourist sites (and there is scarcely anywhere or anything that has not been) so a multitude of businesses and agencies that mediate, facilitate and service the tourist form rhizomic accretions at all levels, simultaneously.

Such a perspective does not dismiss other theorisations of tourism. It does not oppose asking what tourism means or how it relates to other cultural forms of ritual, ludic play, pilgrimage, consumption or the carnivalesque, but it does avoid reducing tourism to basic (often binary) structural forms. This explicitly anti-structuralist and posthumanist hybrid of actor network and Foucauldian analysis, as expressed in works by Crook, Law, and Kendall and Wickham, encourages us to ask not what tourism means but what it does, to deploy a sociology of verbs not nouns. It also encourages us to investigate its becoming and its biography as an ordering and in so doing helps us to grasp its essentially modern and modernising ontology. It reveals a very close linkage with other orderings such as the ordering logistics of modern warfare (Thomas Cook was of great interest and importance to the British foreign office and military and is credited as being an important ingredient in its assemblage and management of an empire), de- traditionalisation (since it interpellates a sense of belonging to a wider world), nationalism (since it valorised an entirely new set of objects, histories, natures and geographies 'of nation') and welfarism. It fits what John Law's describes as a 'dream of ordering', as a form of management and a socio-technical ontology.

From this perspective tourism is not fragmented into a repetition of sites and an eternal present, but a formidable socio-technical rhizome, in a globalising line of flight, with a series of substantial ordering effects. In its becoming it established one of the most important networks of connectivity that contributed to (and made possible) globalisation. In this sense tourism has become a key cultural form of translation across the world and can hardly be confined to the social margins, resorts enclaves and times away from home. Indeed, tourism as I would have it (and I press for a new ontology rather than a replacement theory) is more or less the exact opposite of its typical theorisation. 
Conceiving tourism as an ordering is in line with a lot of other emerging tourism theory (if that is an appropriate word to use), particularly as regards the agency of tourism objects which is an area that has been much neglected. Haldrup and Larsen's (2006) paper is a useful summary of the intertwined and therefore theoretically central role of objects in tourism and the hybrid human-material cultures they reveal, while Johannessson (2005a, 2005b) and Baerenholdt and Haldrup (2004) have begun to use Actor-Network Theory to investigate particular tourist sites as socio-technical networks.

These make the case for an analysis beyond Appardurai's 'the social life of things' towards the more symmetrical application of agency to all objects (human and nonhuman) in tourism. This opens up a new area for investigation, particularly those poorly understood spaces of mobility and the social relations between humans and the technologies of travel and mobility.

However, perhaps the greatest potential benefit of viewing tourism as an ordering derives from being able to see it in its global scope and operation. As Crang and I (2001) argued, all too often tourism research is mired in the tourist site, the resort or location and tourism's wider social and cultural impacts and effects are less clear and rarely the subject of sociological and anthropological investigations. It is for this reason perhaps that its main evaluations are in terms of local impacts and effects. While global tourism cannot be conceived as a subjectivity, it is a remarkably linked set of companies, organisations, technologies and cultural predispositions and values. As a global system a lot depends upon it, and our confidence in it to deliver safe, smooth and pleasurable passage from one place to any other. Seen as an ordering of people, cultures and places, and experience it becomes possible to evaluate its wider impacts and effects and the last part of this paper is intended to identify some very significant effects that merit further scholarship.

\section{Ordering Effects}

As a global tourism ordering developed and extended it did so in two important and linked senses. It ordered individuals as touristic, as travel orientated, world-curious with touristic repertoires and connoisseurship. Contemporary critics of tourism who name the tourism phenomenon as mindless might care to recall their last few trips for it is not true that travel and tourism are passive. They require much work and organization, far more because it is outside the everyday world of norms and routine and involve much more stress, if only because unlike everyday life the logistics are more fine-tuned and with far more at stake (de Botton 2002, rightly regards travel as an art). But we also forget perhaps that it takes experience, skill and practice to remain calm, relaxed, trusting and motivated when on the move and in very new settings. These are ordering effects we have learned to take for granted, but we must recall those brass bands and the crowds who turned out to see Thomas Cook's first guided tour parties, tourists whose novelty and audacity was something to see.

Second, the tourism ordering (re)orders places, spaces, cities and cultures, leaving them changed in specific ways. In some instances tourism has become a place-maker by creating an entirely different way of configuring, knowing, desiring, visiting and living in places previously untouched by tourism. The simple act of mapping a set of streets and producing a narrative history to enable visitors to grasp what it is they see as they roam them alters a place, both for outsiders who might now feel comfortable there and its inhabitants who may feel that their place has wider significance and part of a broader sweep of history. 
In this final section then I want to gather together these and other ordering effects that properly belong to the tourism ordering, but yet are often lost in the vagaries of globalisation. Typically, the net effect of tourism in the world is regarded by social scientists as at best ambiguous and at worst negative. Income from tourism in many tourism-dependent localities has been exported to overseas investors rather than finding its way into local forms of investment while local political interests have often been eclipsed by the tourism interest. While I want to recognise that in many sectors of the world tourism has brought poverty, powerlessness and reduced life chances (see Meethan 2001), I would not want this truth to pre-empt a discussion of its broader but less routinely considered benefits.

\section{Aestheticisation}

Tourists are often accused of an indifference to the places they visit; it is said that they return to their everyday lives as privileged consumers unchanged. But the history of tourism ordering suggests this is not so. If anything has undermined the stability and ethnocentricity of beauty and attraction it is certainly travel and tourism. Before there was anything like market segmentation and choice, tourism was among the earliest sources of variety and this disturbed established and unchanging canons of aesthetic beauty, even those high cultural attempts to define them in absolute terms. Part of this disturbance was the aestheticisation of everyday objects, elsewhere. Tourists and travelers are confronted by a world of everyday objects elsewhere that are compelling because they are at once the same but different. These are not merely to be seen as curiosities but performed: eaten, used, bought, exchanged, taken home and gifted. They become part of the performance and connoisseurship of the tourists and in this way become part of their own taste repertoires, and that can indeed lead to their eventual addition to everyday consumption, as was the case with the travel of Mediterranean food, colour, design and culture into northern Europe following the advent of mass tourism to southern Spain. In the 1970s it was the case, as my friend Philip Colechin who lived in Notting Hill (London) recently reminded me, that if you wanted avocados, green peppers and chillis then you had to travel into Soho to make your purchase. This was an outing in its own right. In most cities none of these items could be bought at all. Yet by the early 1980s they were freely available in great variety and colour from every corner store and supermarket. This was not globalization closing in on northern Europe; it was Spain consolidating a market that was established through touristic practice, through the willingness of tourists to add to their palette. The Mediterranean was plundered for its aesthetic appeal long before supermarket peppers. In the 1950s and 1960s designers and artists formed part of an advanced party of travelers to the region, especially the French Riviera, and brought back both the colours and the everyday objects, and offered them to a mass market as curtain and dress material, wallpaper, crockery designs and giftwares. Indeed this aesthetic love affair with the region was part of the reason why it became such a tourism success story with the advent of cheaper air travel. "More and more of elements of reality are being aesthetically mantled", argues Wolfgang Welsch, and he finds it hard to believe: "hardly a paving stone, no door handle and no public place has been spared by the aestheticisation boom" (Welsch 1997: 1-2). The idea that everything can and might be or "is in principle capable of being' considered beautiful or attractive or interesting is new and it relates to the developing connoisseurship of tourists for this is the terrain of their wonderment. 
As a creature born into and conditioned both by tales the exotic sublime and the dangers of eighteenth century exploration and travel, Xavier de Maistre knew only too well that the most pleasing things to be told about were the basics, food, nature, tools and clothes or their absence. So much can be said about ordinary objects that de Maistre saw no reason why the traveler needed to go so far, and in 1790 he decided to embark on a journey around his bedroom, a tour later published as A Journey Around my Bedroom and later followed by Nocturnal Expedition around my Bedroom with encouragements for others to pursue other room tourism, especially "to the poor and to those afraid of storms robberies and high cliffs" (de Botton 2002: 245). While Alain de Botton (2002) followed in his footsteps some two hundred years later in Hammersmith (London), obeying the mental command "to look around me as though I had never been to this place before", there is nothing particularly new here if we realize that this is precisely what most tourism developers do in most places, this is what breweries did to their pubs and this is what museums are doing with modern household objects. We can look and do look at our everyday world through the eyes of tourists because like flanerie before, our consumerist worlds are in constant flux. Now that the world travels to us just as much as we travel to it, it is a practical matter to remain in tourist mode wherever we are.

\section{Consumerism}

For Meethan (2001), tourism is merely the extension of commodification but this gloomy conclusion reduces tourism to an artifact of commerce when it is far more spectacular than that. We know that a romantic sensibility accompanied Thomas Cook as he guided his tourists and we know that they were told to read Scott's romantic novels as mental preparation for his so-called 'Tartan Tours' of Scotland in the 1850s. Although Cook's guided tours were always on the move and held to impossible itineraries, they were also very exacting physically and mentally as the diaries and journals of early tourists testify (Morrell 1998). Cook required his tourists to appreciate properly the scenery, architecture, ruins and natures of the tour. And this proper mode of appreciation, the romantic sensibility, required the tourist to conjure the beauty of their gaze using language, poetry, and an essentially imaginative disposition. The pleasurability was not the consumption of the object itself so much as the self-generated sense of desire. Indeed the desire for the Alps, which Jemima Morrell anticipated in her head, was as intense and as pleasurable as the real thing (Morrell 1998). Colin Campbell (1995) suggests that this capability was entirely new to the tourist gaze and gave rise not only to a demand to visit such places but the habit of applying it to other forms of consumption. Whereas before the pleasure of consuming things was to be had mainly in the physical dimensions of taste and use, the romantic sensibility gave rise to the pleasures of anticipation and desire ahead of its physical consumption. And, like the tourist gaze itself, the eventual possession of the object can be tinged with anticlimax, as the real thing never quite matches the intensity of desire and pleasurability of its anticipation. Disappointment for the tourist can be accompanied by restlessness, to be off quickly without further ado to the next thing to see. And after this manner, consumption also became restless, driving a longing for another thing not yet in our grasp. Bauman quotes Taylor and Saarinen (n.d.) who say 'desire does not desire satisfaction. To the contrary, desire desires desire (Bauman 1998: 83). Campbell's insight is important and should be followed up by exploring the links between tourism and other areas of everyday life. 


\section{Translation}

Orderings extend, in part, through processes of translation which is as much cultural as it is sociotechnical: Latour's translations "create mixtures between entirely new types of beings, hybrids of nature and also culture" (Latour 1993:10). The tourism ordering created and continues to create an expanding network based on translation, mapping, enrolment and interpretation work. In this sense it is ethnographic work, making different cultural milieu accessible and explicable to those from other cultures and places. Indeed it is best described as an exercise in eternal translation. But also sociotechnical work, translation between the social and the technical producing 'automobility', the 'excursion', the 'train', or Dant's (2004) 'driver-car'. Again, we have come to take this for granted but the world has been made available to the universal traveller through tourism. We tend to forget how difficult this is before tourism's translation work. All places, times, peoples, cultures, etiquettes, languages required translation work for the generalised and specific stranger-visitors, thus opening up the world to greater penetration, mobility and exchange. There is a lot of this material generated through tourism ordering from city guidebooks and street maps to Lonely Planet, Rough Guides, travel writing and so on. Translation leaves places changed, reorders them completely. It creates new narratives of place and culture, new marketing devices, reputations, and icons that are detachable and attachable to other commodities. Further research must delve more into the archives of this translation and also rewrite city and place histories from the point of view of their tourism ordering. In their Venice, The Tourist Maze, Davis and Marvin (2004: 2) write for instance that "the tourist Venice is Venice".

\section{Place-making}

Prior to tourism orderings, most villages, towns and regions were inward looking despite multiple trade networks. Their sense of 'place' as a distinctive, relative, narrative was rare before tourism. Through translation and interpretation, selection, bracketing, staging etc, towns and regions, people and cultures were framed as place, with 'place effects'. It is when a town's reputation to outsiders begins to take on a life of its own, directing the course of planning, building, literature, work and art that we can talk of place effects (Duncan and Savage 1989). The tourism ordering then creates the 'placemaking imperative': most if not all seek to identify their 'place' for the consumption of others (coal mines turn into museums in Wales, industrial past advertised in Bradford, etc.) Place-making is not purely commercial and exploitative. As Sharon MacDonald shows, it is also used by those ignored or sidelined by 'history' and politics and provides localities with a means to assert/ place themselves (MacDonald 1997).

\section{Touristification}

I would not be the first to say that tourism has become something of a metaphor for modernity or at least modern societies (that honour belongs to Dean MacCannell and in a different way to Zygmunt Bauman who emphasizes that it is the 'looseness of attachment' that makes tourism such an apt metaphor), but tourism is also in the performative sense a stance to the world, a way of navigating ourselves around our complicated world and being navigated by it (Bauman 1998). Many things have been reordered by tourism from shopping to eating out, watching TV, surfing the net, marketing, branding and so on. Australia was quite explicitly rendered anew through its branding for tourists. For example, 
the Internet makes the point well. The Internet has been configured in the likeness or ordering of tourism. We 'visit' web 'sites'. We wander around sites as the mood takes us, leisurely or erratically; sites provide us with 'maps' and when we arrive anywhere (why do we feel we arrive?) we are given itineraries, menus, gateways, guides, access, tours, guided tours. It is a language of movement, 'back', 'forward', 'go', 'stop', 'search', 'find', and so on. There is also something touristic about the way sites are constructed, they aim to attract us, make us linger, entertain us and sell. Information is presented as a journey, a pleasure; to be uncovered by serendipity. Even people, individuals have rendered themselves as tourist sites through their own web pages. I have seen 'welcome to me' signs as if I had just driven into a little town.

Why is it that tourism has proved such a winning language and etiquette for life generally in contemporary societies? Is it because solid socialities and separable lifeworlds no longer exist, that everything has been penetrated and translated by mobility? Or that the mobile and fluid world turns us all into tourist wherever we are? Clearly more ethnography work needs to be done and the tourism ordering suggests that new tourist research should favor the everyday as much as the resort and 'destination'.

\section{Cosmopolitanism}

While touristic ties can be described as necessarily loose and 'until further notice' (this is another of Bauman's catch phrases from his notion of 'liquid modernity') this does not mean that serious and enduring positive effects cannot be attributed to the tourism ordering. The Anglophilia-Francophilia phenomenon was a love affair born of tourism. It might be a one-sided relationship with practitioners of the latter far outnumbering those of the former, but it is a tangible and important effect giving rise to successful town twinning, student exchanges, the exchange of art, music and literature, and the erosion of very longstanding negative stereotypes. This is a good example to use because it was the explicit wish of Thomas Cook that tourism would undermine the historical animosity between the French and the British. At the silver jubilee celebration of Thomas Cook and son, John Cook said that it was his father's belief "that the world would be a pleasanter place of habitation if all the dwellers on its surface were brought closer together, and that international travel was one of the best preservatives against international war, since it dissipated absurd notions and dangerous prejudices" (Brendan 1991: 66). Sadly it takes more than this to prevent wars but it is far more difficult to demonise others if they are already understood, known, liked and admired. Critics also warn that tourism can and does breed blasé, worldly indifference on the one hand and the beach lager lout on the other. This must be conceded, but at the same time there is nothing about the sociology of orderings that argues they always succeed, indeed failure is just as likely. The humanitarian gains of tourism are probably mixed. Certainly the phenomenology of heritage tourism shows that far from being indifferent the range of interpellations and engagements with others' histories probably account for its success. In a similar way the trend towards the Japanese fondness for "skin tourism" (Reiko 1991), getting closer to local culture, the growth of backpackerism and the growth of sensual over visual tourism all emphasis that the 'tourist bubble' has burst. At the very least Mark Twain was surely correct to point out that tourism undermines prejudice through a range of testing exchanges: because it permits controlled experiments in ethnography; because Others become entwined in acts of self-making; because we are accepting and moved by the kindnesses of strangers; 
because tourism makes Others seem more like us than otherwise, exposing a common humanity. Finding that common humanity and nurturing it is what Cook thought was possible through the socio-technology of tourism, and while it is an irony that Bauman feels we must not give up the search, despite tourism, despite the looseness of touristic ties generally, his wish for global governance and re-order may only come to fruition through the skills and repertoires we learn as tourists: when everyone feels as strongly about their world as they once did about their nation (see Franklin 2003b).

\section{References cited}

Adamson, Donald (ed.), 1996. Rides Round Britain by John Byng. London: The Folio Society.

Baerenholdt, Jorgen O., and Michael Haldrup, 2006. European Urban and Regional Studies, 13 (3), pp. 209-224.

BAUMAN, Zigmunt,

1998. Globalisation. Cambridge: Polity Press.

2000. Liquid Modernity. Cambridge: Polity Press.

Bennett, Tony, 1983. "A Thousand and One Troubles: Blackpool Pleasure Beach”, in Formations of Pleasure, pp. 138-55. London: Routledge and Kegan Paul.

Botтon, Alain de, 2002. The Art of Travel. London: Hamish Hamilton.

Brendan, Piers, 1991. Thomas Cook: 150 Years of Popular Tourism. Berkeley: University of California Press.

CAmpbell, Colin, 1995. The Romantic Ethic and the Spirit of Consumerism. Oxford: Blackwell.

Clifford, James, 1992. "Travelling Cultures", in L. Grossberg, C. Nelson and P. A. Treichler (eds), Cultural Studies. New York: Routledge.

CROoK, Stephen, 1999. "Ordering risks", in D. Lupton (ed.), Risk and Sociocultural theory: new directions and perspectives. Cambridge: Cambridge University Press.

DANT, Tim, 2004. “The Driver-car”, Theory, Culture and Society, 21 (4/5), pp. 61-79.

Davis, Robert C. and Garry Marvin, 2004. Venice, The Tourist Maze. Berkeley: University of California Press.

Doquet, Anne and Olivier Evrard, 2008. “An Interview with Jean-Didier Urbain”, Tourist Studies, 9 (2).

Duncan, Simon S. and Mike Savage, 1989. "Space, Scale and Locality”, Antipode, 21 (3), pp. 179-206.

Franklin, Adrian S. and Mike Crang, 2001. "The trouble with tourism and travel theory?", Tourist Studies, $1(1)$, pp. 5-22.

FrankLIN, Adrian S., 2003a. Tourism. London: Sage.

2003b. "The Tourism Syndrome: An Interview with Zygmunt Bauman", Tourist Studies, 3 (2), pp. 205-218.

2004. "Tourism as an ordering: towards a new ontology of tourism", Tourist Studies, 4 (3), pp. 277-303.

2007. "The problem with tourism theory", in Irena Ateljevic, Nigel Morgan, Annette Pritchard and Candice Harris (eds), The critical turn in tourism studies: Innovative research Methodologies, pp. 131-148. London: Elsevier.

2008. "The Sociology of Tourism", in T. Jamal and M. Robinson (Eds), Sage Handbook of Tourism Studies. London: Sage. 
Granovetter, Mark, 1973. "The Strength of Weak Ties”, American Journal of Sociology, 78 (6), pp. 13601380.

Haldrup, Michael and Jonas LARSEn, 2006. "Material Cultures of Tourism”, Leisure Studies, 25 (3), pp. 275 289.

Hunt, Alan and Gary Wickham, 1994. Foucault and Law: Towards a Sociology of Law as Governance. London: Pluto Press.

JohanNESSON, Gunnar T.,

2005a. "Placing Tourism: The Ordering of a tourism project in Westfjords-Iceland. The Inaugural Nordic Geographers Meeting”, Power over time-space, Lund, Sweden, May, 10-14, pp. 1-30.

2005b. "Tourism Translations: Actor-Network Theory and Tourism Research", Tourist Studies, 5 (2), pp. 133-150.

Kendall, Gavin and Gary Wicкham, 2001. Understanding culture: cultural studies, order, ordering. London: Sage.

Lash, Scott and John UrRY, 1994. Economies of Signs and Space. London: Sage.

LARSEn, Jonas, 2006. Picturing Bornholm: "Producing and Consuming a Tourist Place", Scandinavian Journal of Hospitality and Tourism, 6 (2), August 2006 , pp. 75-94.

Latour, Bruno, 1993. We Have Never Been Modern. New York: Harvester Wheatsheaf.

LAw, John,

1994. Organizing Modernity. London: Sage.

2003. "Ordering and Obduracy", published by the Centre for Science Studies, Lancaster University, Lancaster LA1 4YN, UK, at http://www.comp.lancs.ac.uk/sociology/papers/Law-Ordering-andObduracy.pdf

Law, John and Kevin Hetherington, 1999. "Materialities, spatialities and globalities", Dept of Sociology, University of Lancaster. http://www.lancs.ac.uk/fss/sociology/papers/law-hetherington-materialitiesspatialities-globalities.pdf, accessed 12.07.06.

MacCannel, Dean, 1976. The Tourist: A New Theory of the Leisure Class. New York: Schocken.

MacDonald, Sharon, 1997. “A People’s Story: Heritage Identity and Authenticity”, in Chris Rojek and John Urry (eds), Touring Cultures, pp. 155-75. London: Routledge.

Meethan, Kevin, 2001. Tourism in Global Society. Basingstoke, Hants: Palgrave.

Morrell, Jemima, 1998. Miss Jemima’s Swiss Journal. London: Routledge.

O'Reilly, Karen, 2000. The British on the Costa Del Sol: Transnational Identities and Local Communities. London: Routledge.

Pickering, Andrew, 1995. The Mangle of Practice. Chicago: University of Chicago Press.

Pi-SunYer, Oriol, 1982. “Tourism and anthropology”. Annals of Tourism Research, 8, pp. 271-284.

ReIKo, Inoue, 1991. “An Army of Japanese Tourists”, AMPO: Japan-Asia Quarterly Review, 22 (4), pp. 3-11.

SHIElds, Rob, 1991. Places on the Margin. London: Routledge.

URRY, John, 1991. The Tourist Gaze. London: Sage.

Welsch, Wolfgang, 1997. Undoing Aesthetics. London: Sage.

Wenkam, Robert, 1975. “The Pacific Tourist Blight”, Annals of Tourism Research, 3, pp. 68-77.

Withey, Lynne, 1997. Grand Tours and Cook's Tours: a History of Leisure Travel, 1750 to 1915. Berkeley: University of California Press.

Young, George, 1973. Tourism: Blessing or Blight? Harmondsworth: Penguin. 